\title{
A geochemical view into continental palaeotemperatures of the end-Permian using oxygen and hydrogen isotope composition of secondary silica in chert rubble breccia: Kaibab Formation, Grand Canyon (USA)
}

Ray Kenny* (D

\begin{abstract}
The upper carbonate member of the Kaibab Formation in northern Arizona (USA) was subaerially exposed during the end Permian and contains fractured and zoned chert rubble lag deposits typical of karst topography. The karst chert rubble has secondary (authigenic) silica precipitates suitable for estimating continental weathering temperatures during the end Permian karst event. New oxygen and hydrogen isotope ratios of secondary silica precipitates in the residual rubble breccia: (1) yield continental palaeotemperature estimates between 17 and $22^{\circ} \mathrm{C}$; and, (2) indicate that meteoric water played a role in the crystallization history of the secondary silica. The continental palaeotemperatures presented herein are broadly consistent with a global mean temperature estimate of $18.2^{\circ} \mathrm{C}$ for the latest Permian derived from published climate system models. Few data sets are presently available that allow even approximate quantitative estimates of regional continental palaeotemperatures. These data provide a basis for better understanding the end Permian palaeoclimate at a seasonally-tropical latitude along the western shoreline of Pangaea.
\end{abstract}

Keywords: Oxygen and hydrogen stable isotopes, Chert, Grand Canyon, Authigenic silica, Kaibab Formation, Permian-Triassic Boundary, End Permian, Chert rubble, Breccia, Subaerial exposure surface, Karst

\section{Background}

The end Permian subaerial erosion surface exposed at the top of the Kaibab Formation (KF) is important because it occupies a time in Earth history that represents the largest and most severe mass extinction in the Phanerozoic [1-3] resulting in a substantial loss of terrestrial and marine life $[4,5]$. A plethora of models and hypotheses have been proposed and discussed [6, 7] to account for the mass extinction event and the catastrophic environmental changes that occurred during the end-Permian event and across the Permian-Triassic transition, including: (1) bolide impacts [8]; (2) catastrophic methane bursts [5, 9-12]; (3) oceanic degassing of hydrogen sulfide

*Correspondence: Kenny_r@fortlewis.edu

Geosciences Department, Fort Lewis College, Durango, CO 81301, USA
[13]; and, (4) massive $\mathrm{CO}_{2}$ release from the eruption of Siberian flood basalts $[14,15]$. Kidder and Worsley [16] have suggested that a significant increase in atmospheric $\mathrm{CO}_{2}$ was present across the Permian-Triassic Boundary (PTB) resulting in global, tundra-free, "warmhouse" climate conditions $[17,18]$. Numerous studies have focused on geochemical evidence preserved as biomarkers that point to global euxinic or anoxic marine conditions [1922]. Chronologic constraints for the end-Permian extinction event and the PTB range from 251.4 to $>254 \mathrm{Ma}$ $[23,24]$. Shen et al. [25] suggest that the mass extinction event lasted for $\sim 200,000$ years with the peak of extinction occurring just before $252.28 \pm 0.08$ million years ago. Kiehl and Shields [26] used reconstructed palaeogeographical data to produce a comprehensive climate model which showed that the Earth was warmer than 
the present, which agrees with other palaeodata, climate models, and palaeoenvironmental studies of the end Permian $[18,19,27-30]$.

The Permian KF is composed of a variety of lithologic types but predominantly is a shallow marine carbonate with subordinate siliciclastic sediment, chert and gypsum [31-35]. In northern Arizona, the KF is uncomformably overlain by fluvial, tidal flat and non-marine sediment of the lower Triassic Moenkopi Formation. The lower member of the Moenkopi Formation is largely composed of strata formed during and after the first eastward transgression of the Panthalassic sea (Fig. 1), and typically consists of a laterally variable yellowish siltstone, sandstone, and grey chert pebble conglomerate and breccia [36]. The uppermost beds of the KF contain spatially extensive palaeokarst depressions [31] and form a laterally uniform, thick, chert-rubble erosion surface in wellexposed outcrops across much of northern Arizona and the Grand Canyon region. McFadden [37] and McFadden and Knauth [38] have shown that the uppermost rubble breccia of the KF contains highly fractured, zoned, slumped and silicified chert, and they argued that: (1) the rubble breccia resulted from extensive dissolution of the carbonate host rock; (2) long-term subaerial exposure began after eustatic sea level regression of the end Permian event; and, (3) the subaerial karst event spans the
PTB and terminated in the lower Triassic Period based on the presence of chert-pebble and chert-rubble conglomerates in lower Triassic fluvial channels, first noted by Huntoon et al. [39].

Most palaeoenvironmental studies of the end-Permian event and the PTB have focused on well-preserved biomarkers in the marine record [40]. In contrast to the large data sets for coastal and oceanic palaeotemperatures, there are few data sets that allow even approximate quantitative estimates of continental (non-marine) palaeotemperatures because well-preserved, terrestrial sedimentary deposits are scarce. Empirical continental evidence predominantly comes from peatlands, palaeosols, and palaeosol carbonate [41-43 and references therein]. However, Peters et al. [44] argue that palaeotemperature estimates of pedogenic carbonates derived from isotopic values have a seasonal variability bias that yield temperature uncertainties. Oxygen and hydrogen isotopic compositions of silica have been successfully used to better understand the crystallization history of chert [45] based on the premise that once the granular, microcrystalline quartz has crystallized the isotopic composition is preserved. Kenny and Knauth [46] and Kenny [47] demonstrated that oxygen and hydrogen isotopic composition of secondary (authigenic) silica crystallized during subaerial exposure surfaces could be used to approximate

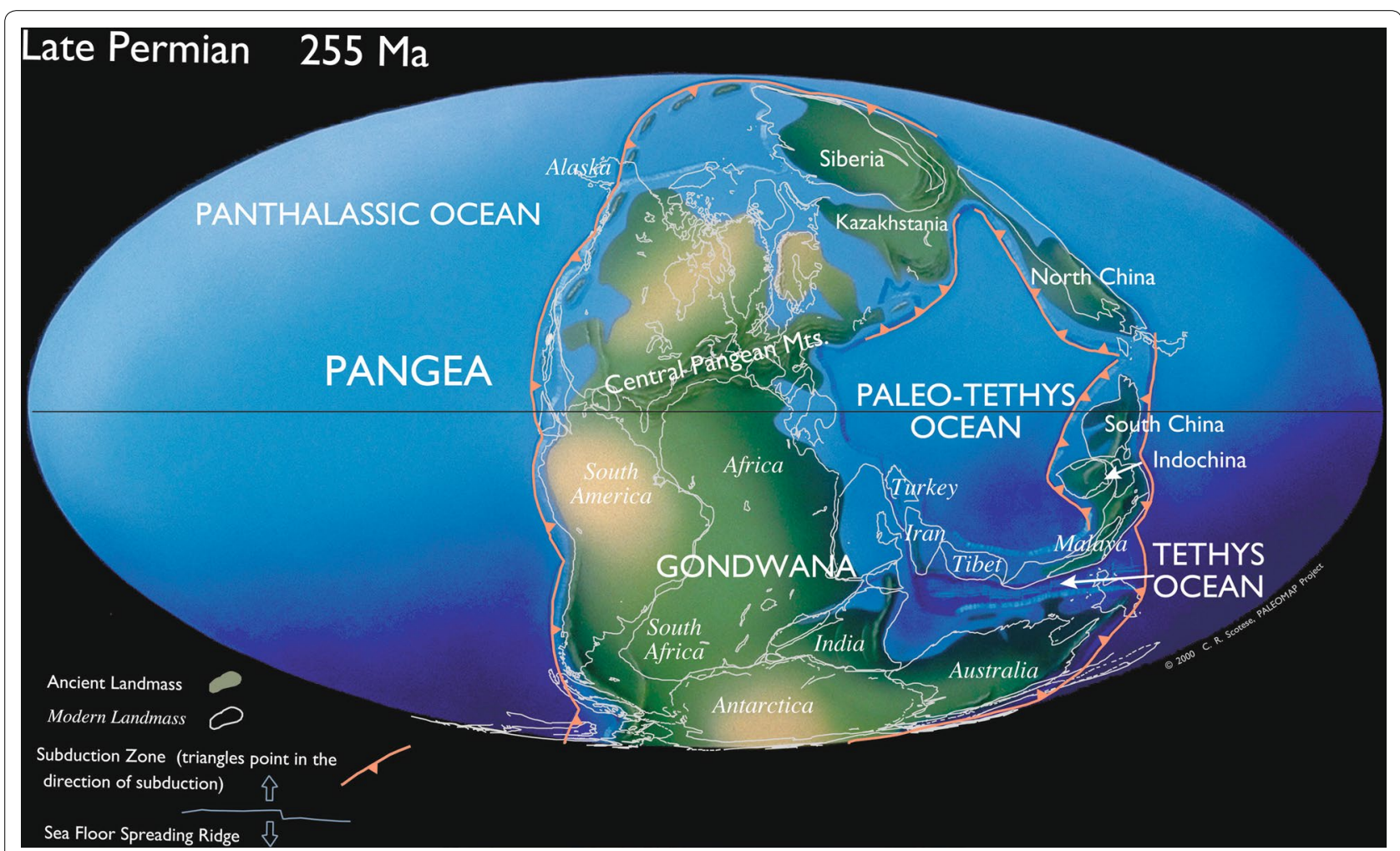

Fig. 1 Palaeogeographic map of the Late Permian (255 Ma) (Used with permission [89]) 
near-surface continental weathering temperatures. Both crystallization temperatures and the role of meteoric waters in the initial crystallization of silica can be gleaned from the stable isotope values. The research hypothesis of this study is that: (1) secondary, drusy, botryoidal, vugfill silica precipitated in the chert rubble of the upper KF could be used to estimate approximate, continental quartz crystallization temperatures for the end-Permian event and across the PTB in northern AZ; and, (2) the isotopic composition of the silica could be used to verify that silica in the chert rubble breccia crystallized in the presence of meteoric (non-marine) waters.
Silica samples were collected from within chert rubble horizons exposed in narrow and slot canyons draining the southeastern edge of the Vermillion Cliffs near Marble Canyon, AZ (Fig. 2). Samples from several wellexposed outcrop localities contained an abundance of secondary silica phases that were recognizable in hand sample (Fig. 3). Secondary silica samples were reduced to millimeter-size $(\sim 2-4 \mathrm{~mm})$ silica chips. The silica chips along with a few hyaline microcrystalline quartz crystals, were meticulously extracted from vugs, voids, and lag deposit interstices (Fig. 4). The millimeter-size sample chips were visually inspected, sorted by translucence and

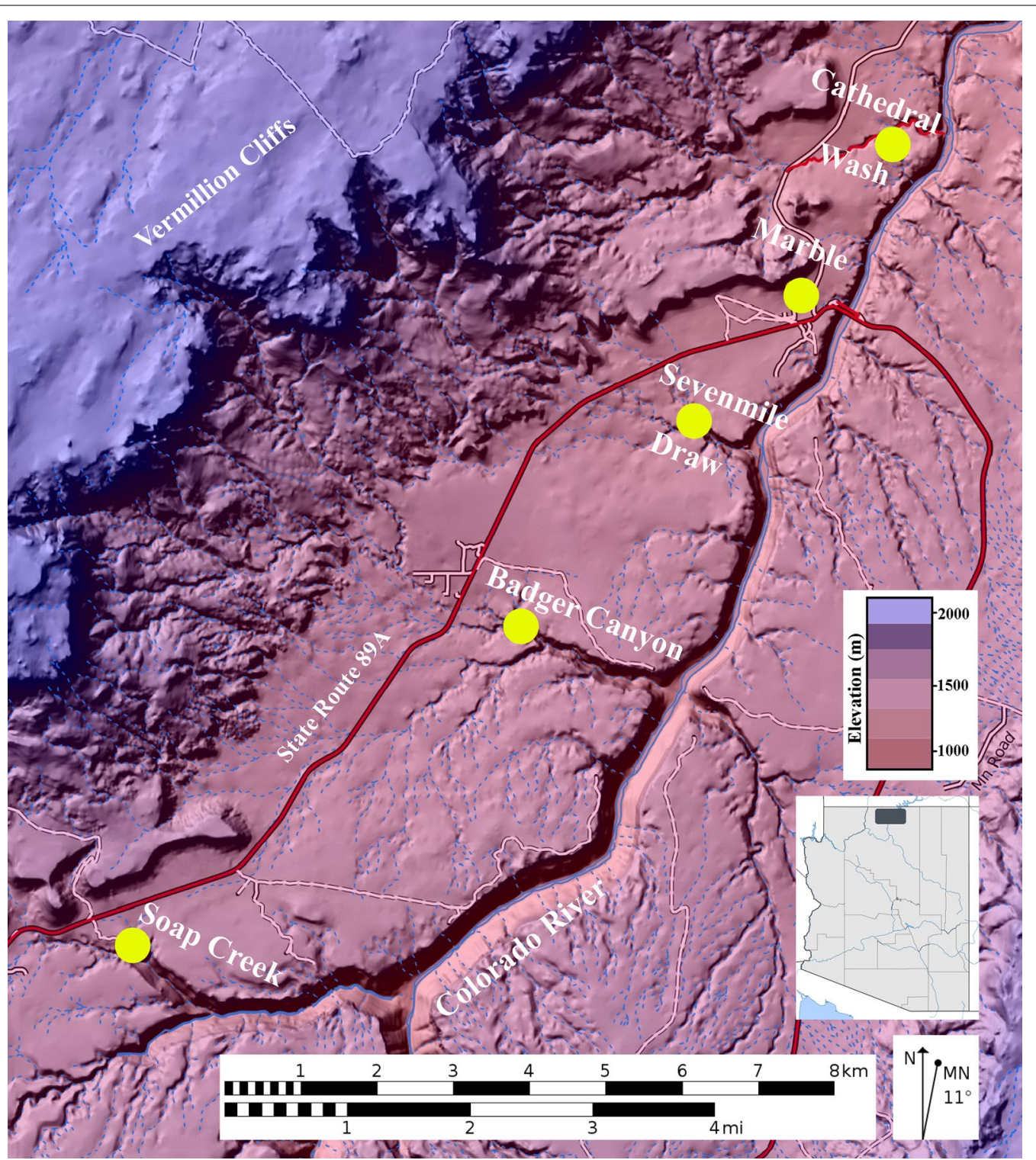

Fig. 2 Secondary silica sample locations in the Marble Canyon area of northern Arizona. Samples were extracted from five Kaibab Formation rubble breccia slot canyon sites 


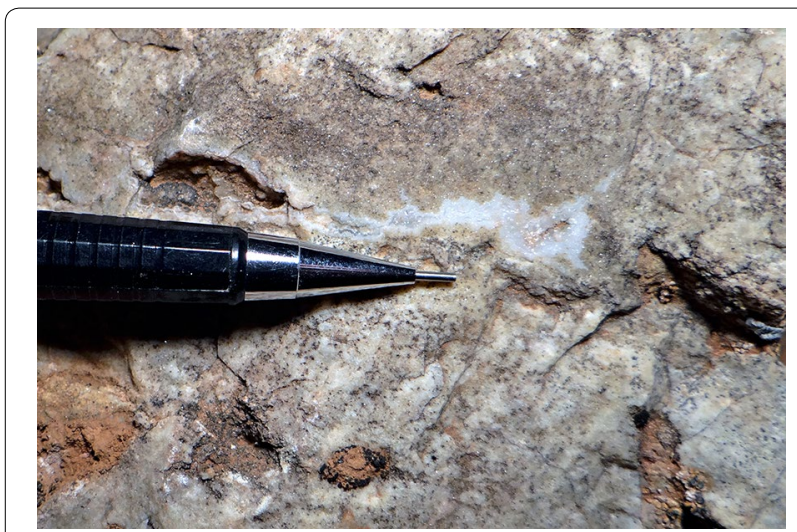

Fig. 3 Example of translucent to white secondary silica from the Kaibab Formation chert rubble breccia (Sevenmile Draw). Vugs are typically rimmed with fibrous silica which transition to drusy quartz toward the middle of vugs, interstices or cavities. Mechanical pencil tip (width) is $0.05 \mathrm{~mm}$

a

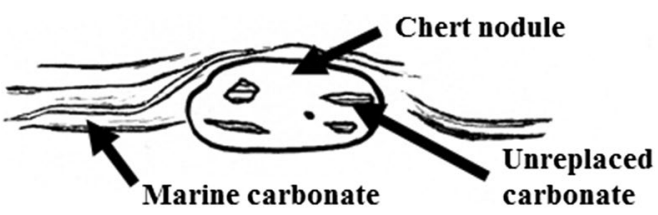

b Chert replaced by secondary silica

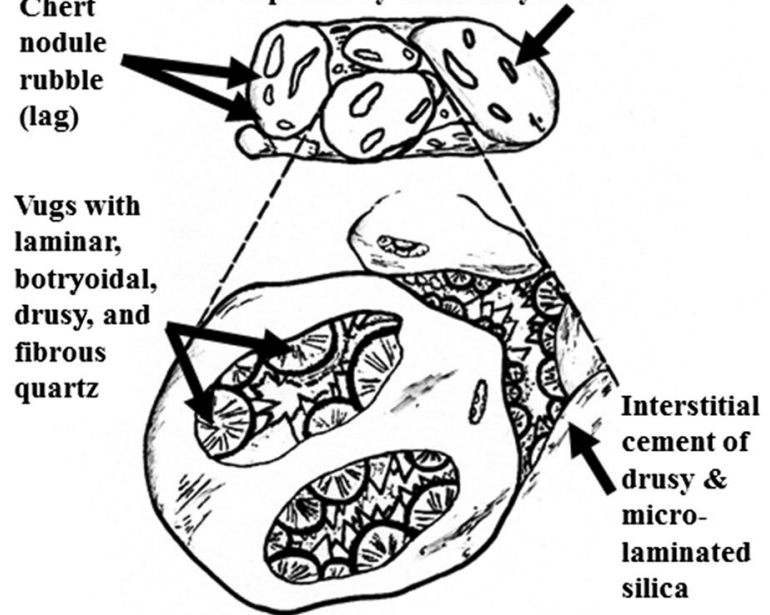

Fig. 4 Diagrammatic sketch contrasting chert-rich, marine carbonate rock and secondary silica and chert rubble deposits in a continental karst terrain. a Early diagenetic, marine carbonate-draped chert nodule with variable percentage of unreplaced carbonate. $\mathbf{b}$ Lag accumulation of resistant, slumped and randomly oriented chert nodules in a continental karst terrain. Unreplaced carbonate is leached out and replaced by secondary, cavity-fill silica which consists of fibrous, botryoidal and drusy quartz (Diagram modified from [46]) color, and analyzed under a binocular microscope for the presence of iron-oxides or other impurities. A hand-held magnet was passed over the sample chips to detect (magnetic) iron-oxide. Samples determined to be free of impurities were selected for stable isotope analysis. Oxygen and hydrogen isotope analyses were conducted following the well-established, in situ laser extraction method of Sharp [48] and Sharp et al. [49] in the University of Texas-Austin stable isotope lab. One silica sample had been previously analyzed in the stable isotope lab at Arizona State University.

\section{Results}

Oxygen and hydrogen isotope ratio data of 15 secondary (authigenic) silica separates from the KF are shown in Fig. 5; the data are given in Table 1. A total of five rubble breccia localities were examined and sampled (Fig. 2). All data are reported relative to V-SMOW in standard $\delta$-notation. $\delta^{18} \mathrm{O}$ values represent total (structural) oxygen of chert and silica; $\delta \mathrm{D}$ values are derived from non-surface hydroxyl groups of chert and silica. All analyses have a precision of \pm 0.2 and $\pm 2 \%$ for $\delta^{18} \mathrm{O}$ and $\delta \mathrm{D}$, respectively. The present data do not allow for precise error estimates, and the ability to assign temperatures on the order of plus or minus several ${ }^{\circ} \mathrm{C}$ does not presently exist.

The oxygen and hydrogen isotope ratio data derived from KF secondary silica separates form domains elongated away from Line $\mathrm{A}$ on a $\delta \mathrm{D}-\delta^{18} \mathrm{O}$ diagram (Fig. 5). Line $\mathrm{A}$ is the inferred locus of isotopic compositions of cherts in equilibrium with modern sea water at various temperatures [45]. Silica data are interpreted in terms of palaeotemperatures by comparing them with temperature lines drawn approximately parallel to the meteoric water line as established by Knauth and Epstein [45]. Silica data elongated away from Line A indicate that meteoric (fresh) waters were involved in the crystallization history of the chert and silica. Palaeotemperature estimates for the secondary silica separates range from about $17-22{ }^{\circ} \mathrm{C}$. The most ${ }^{18} \mathrm{O}$ - and $\mathrm{D}$-depleted samples are likely those with the purest amount of authigenic silica. These are represented on the diagram by four samples which plot closer to the warmest palaeotemperature estimates of $\sim 21-22{ }^{\circ} \mathrm{C}$ (Fig. 5). The silica data indicate that the palaeoclimate at the time of silica crystallization was warm.

\section{Discussion}

During subaerial exposure and the development of karst terrain in chert-rich carbonates, insoluble chert nodules accumulate as chert rubble lag deposits [46]. The 


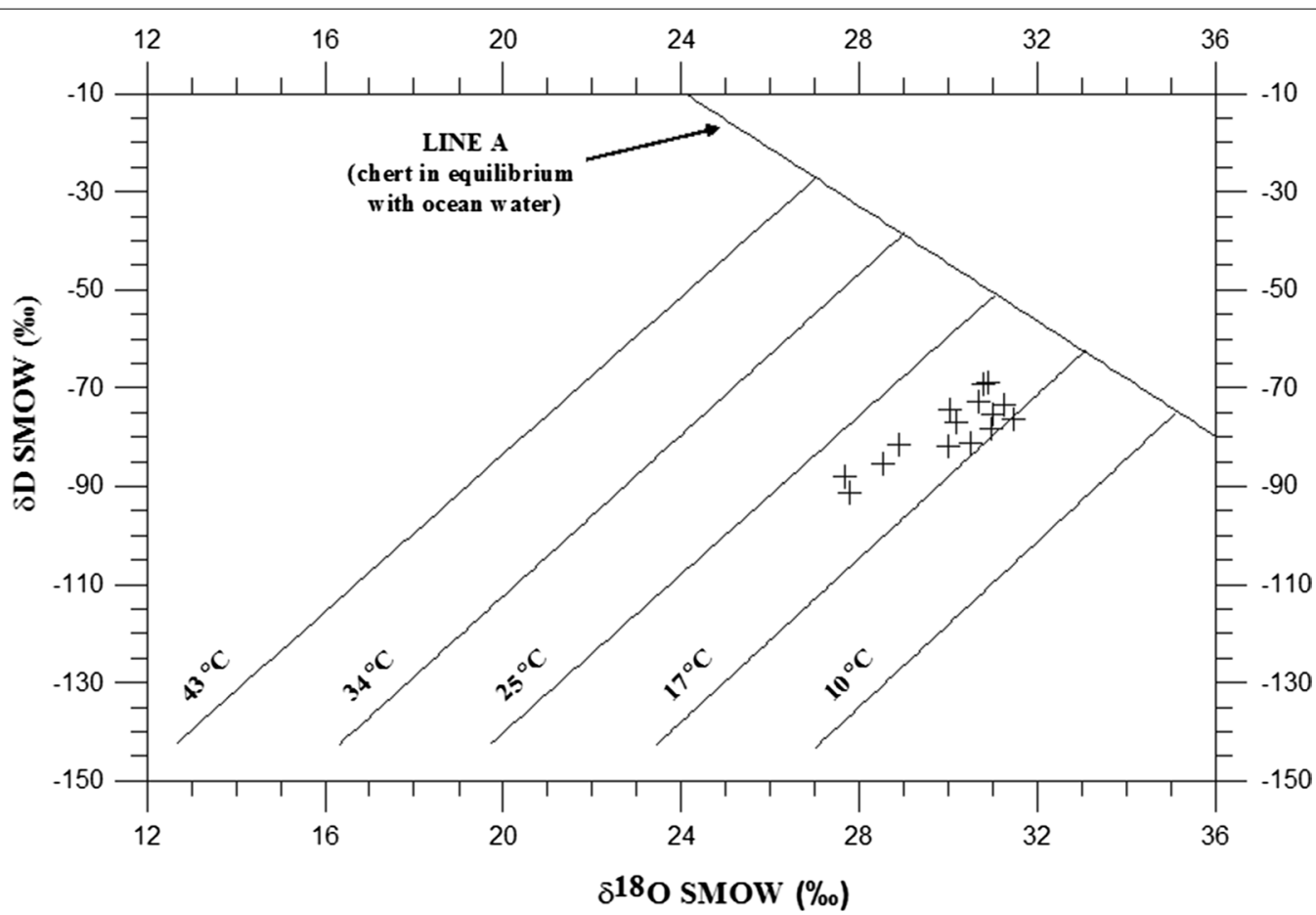

Fig. $5 \delta^{18} \mathrm{O}$ vs $\delta \mathrm{D}$ diagram showing the isotopic compositions of 15 secondary silica samples extracted from Kaibab Formation rubble breccia lag deposits. The oxygen and hydrogen isotope ratio data of secondary silica separates form domains elongated away from Line A. Line A (actually more of a band) is the inferred locus of isotopic compositions of cherts in equilibrium with modern sea water at various temperatures [45]. Silica data elongated away from Line A indicate that meteoric (fresh) waters were involved in the crystallization history of the silica. Silica data are interpreted in terms of palaeotemperatures by comparing them with temperature lines drawn approximately parallel to the meteoric water line [45]. Palaeotemperature estimates for the secondary silica separates range from $\sim 17$ to $22{ }^{\circ} \mathrm{C}$. The most ${ }^{18} \mathrm{O}$ - and D-depleted samples are likely those with the purest amount of authigenic silica. These are represented on the diagram by four samples which plot farthest from Line A and closer to the warmest palaeotemperture estimates of $\sim 21-22^{\circ} \mathrm{C}$

Table 1 Description, data and location of fifteen Kaibab Formation secondary (authigenic) silica samples extracted from the end-Permian chert rubble breccia (northern Arizona)

\begin{tabular}{lll}
\hline $\mathbf{S}^{\mathbf{1}} \mathbf{O ~ S M O W ~ ( \% )}^{\mathbf{a}}$ & SD SMOW (\%o) & Description and location of secondary silica samples \\
\hline 30.8 & -74.5 & Drusy, vug-fill silica (Marble Canyon; KNB1) \\
30.6 & -70.0 & Drusy, vug-fill silica (Soap Creek; SC2) \\
29.7 & -87.8 & Translucent, microcystalline silica vug-fill (Badger Canyon; BC1) \\
30.8 & -77.6 & Translucent drusy, vug-fill quartz (Marble Canyon; MC22) \\
29.9 & -76.1 & White, translucent granular microcrystalline silica (Badger Canyon; KF1) \\
30.6 & -73.6 & Translucent granular microcrystalline silica (Marble Canyon; K6) \\
30.99 & -78.0 & White, translucent granular microcrystalline silica (Badger Canyon; KF2) \\
31.01 & -75.7 & Translucent, dull botryoidal silica (Sevenmile Draw; K7) \\
28.52 & -86.2 & Translucent, granular microcrystalline silica (Sevenmile Draw; K5) \\
31.5 & -77.0 & White, translucent granular microcrystalline silica (Marble Canyon; NB1) \\
30.9 & -68.9 & Translucent, granular microcrystalline silica (Soap Creek Canyon; SC3) \\
30.46 & -80.8 & Translucent, dull botryoidal silica (Sevenmile Draw; 744) \\
28.9 & -82.0 & White, translucent granular microcrystalline silica (Marble Canyon; NBK) \\
27.7 & -92.0 & White, pale blue fibrous silica (Cathedral Wash; NB3) \\
27.8 & -87.42 & White, translucent granular microcrystalline silica (Cathedral Wash; NB5)
\end{tabular}

${ }^{a}$ Reproducibility for $\delta^{18} \mathrm{O}$ is $\pm 0.2 \%$ and $\delta \mathrm{D}$ is $\pm 2 \%$. Reproducibility is based on duplicate runs and standards 
precipitation of secondary silica in karst terrains occurs when downward-percolating meteoric waters reach the saturation level of quartz ( $6 \mathrm{ppm})[50]$ or amorphous silica $(\sim 80 \mathrm{ppm})$ while passing through the chert rubble breccia $[46,51]$. The dissolution of quartz in water results from a straightforward hydration process to form silicic acid, but the dissolution rate is considerably variable depending upon local environmental conditions [52]. Complexing of silicic acid with certain organic acids, which typically occur in tropical karst environments, has been shown to increase quartz solubility [53]. Livingstone [54] documented that in high-rainfall areas, conditions typically associated with tropical karst environments, significantly higher silica content occurs in waters draining known silica sources. White et al. [55] suggested that during karst development, quartz first hydrated to the more soluble opal mineral. However, Martini [56] and Chalcraft and Pye [57] showed that the transformation of quartz to opal is not thermodynamically possible at surface conditions. MacKenzie and Gees [58] grew $10 \mu \mathrm{m}$-sized euhedral microquartz at $20{ }^{\circ} \mathrm{C}$ in 2 years, which suggest that there is no a priori reason that quartz cannot form from silica solutions carrying $>4$ ppm dissolved silica [58]. Rimstidt [59] predicted from experiments done in pure water that the solubility of quartz would be $11 \mathrm{ppm} \pm 1.1 \mathrm{ppm}$ at $25^{\circ} \mathrm{C}$. Knauth [60] argued that there is no compelling evidence that opal is a necessary precursor to microquartz precipitates in any epicontinental replacement cherts. The prominence of drusy and botryoidal silica phases in KF chert rubble vugs suggest that quartz precipitated directly without opaline percursors, and stable isotopic data show clearly that the microquartz sampled from the paleokarst horizons precipitated from waters that had a meteoric water component. The source of the silica can come from dissolution of fine-grained quartz leached out of carbonate during infiltration and/or capillary rise of meteoric water. Skotnicki and Knauth [61] documented nearly complete replacement of karst features and flowstones by secondary silica phases in the Mescal Limestone of northern Arizona. Those authors suggested that the widespread replacement resulted from intense weathering of the Mescal carbonate and the presence/release of an abundant silica source. On a smaller scale, Hill and Forti [62] suggested that calcite replaced by silica in some speleothems likely resulted from $\mathrm{pH}$ fluctuation. Although the precise mechanism for precipitation of secondary silica under subaerial erosion surfaces is not entirely clear, stable isotopic analysis of silica unequivocally indicate that the silica did not precipitate in the presence of marine water and that meteoric water played a role in the crystallization of secondary silica.
Analyses of oxygen and hydrogen isotope ratios of chert and silica have yielded reasonable and reproducible palaeoclimate estimates that have been independently verified with proxy data which are resistant to alteration and isotopic exchange, including clay minerals and ironoxyhydroxide material [63]. Oxygen and hydrogen isotope ratios of chert and silica reliably record the isotopic composition of total oxygen and trace hydroxyl groups preserved in chert at the time of crystallization [45]. Approximate palaeoclimate estimates based on analyses of oxygen and hydrogen isotope ratios of marine chert are well established [45, 64, 65]. Kenny and Knauth [46] demonstrated that oxygen and hydrogen isotopic composition of secondary (authigenic) silica precipitated in palaeokarst chert lags could be used to estimate near-surface continental weathering temperatures as far back as the Late Proterozoic. Kenny [47] reported continental weathering temperatures inferred from oxygen and hydrogen measurements of secondary silica precipitated during a tropical karst event that developed on the Mississippian Redwall Limestone of northern AZ (USA). Abruzzese et al. [63] suggested that oxygen and hydrogen isotope ratios of freshwater chert could be used as an indicator of regional climatic variation in the Cenozoic and concluded that early diagenetic chert likely record surface conditions. Despite the fact that chert and silica have been successfully used to estimate palaeoclimatic conditions, the temperature assignments made with the Knauth and Epstein [45] approach are subject to several uncertainties. (1) The curve for quartz-water isotope fractionation with temperature has not been experimentally verified for low temperatures. The calculated temperature lines, used in this approach (Fig. 5), are extrapolated from well understood, slightly higher-temperature, quartz-water curves [45]. Sharp et al. [66] investigated $\Delta^{17} \mathrm{O}$ variations in low temperature quartz samples in an effort to constrain the temperature of the water from which the quartz precipitated. The authors outlined a number of assumptions and derived a quartz-water fractionation-temperature relationship for low temperatures. This new quartz-water fractionation-relationship may yield a 1 or $2{ }^{\circ} \mathrm{C}$ decrease in temperature estimates relative to the original temperature extrapolations made by Knauth and Epstein [45]. A 1 or $2{ }^{\circ} \mathrm{C}$ temperature change is within the error range for the current temperature assignments, which is on the order of plus or minus a few ${ }^{\circ} \mathrm{C}$. As such, the temperature estimates for this and previous studies are imperceptibly impacted by the new quartz-water fractionation-temperature relationship for low temperature developed by Sharp et al. [66]. If future work on low-temperature, quartz-water fractionation-temperature relationships yield significantly different temperature estimates, then 
the temperatures derived from our approach will need to be adjusted accordingly. (2) Stable isotope ratios of chert must be preserved through time. Microorganisms embedded in Precambrian chert attest to the chemical integrity and physical stability of chert $[64,67,68]$. Remarkable preservation of microorganisms [e.g. 68-72] and previous oxygen and hydrogen isotope ratio studies of chert by Kenny and Knauth [46] suggest excellent preservation of original isotopic values of chert dating from the Late Proterozoic. Brasier et al. [73] argued that some of the oldest, previously reported bacterial microfossils from the $~ 3.5$ Ga Apex Group chert may be geochemical artefacts; other Late Proterozoic microfossils preserved in chert have not been disputed. New research by Schopf et al. [68] has now confirmed the existence of bacteria and microbes in the 3.465 billion year old, Western Australian Apex Group chert. (3) The temperature estimates in Fig. 5 also depend on the assumption that $\delta^{18} \mathrm{O}$ values of sea water have not changed significantly throughout geologic time. The generally lower $\delta^{18} \mathrm{O}$ values of ancient carbonates (e.g., from the Silurian Period) have been used as an argument that $\delta^{18} \mathrm{O}$ values of the past oceans were lower than modern values [74, 75]. Knauth and Roberts [76] provide arguments that they consider fatal to using carbonates to monitor the oxygen isotope composition of past seawater. Knauth and Roberts [76] presented data, including direct analysis of unaltered ocean water preserved in halite, which precludes the proposed 5-6\% oxygen isotope ratio changes in seawater as far back as the Silurian Period. In order to adequately determine the diagenetic history of carbonate samples used to monitor the oxygen isotopic composition of past seawater, both ${ }^{13} \mathrm{C}$ and ${ }^{18} \mathrm{O}$ co-variant values are needed. Veizer and Prokoph [75] analyzed oxygen isotope ratios of carbonates to propose secular oxygen isotope ratio changes in ocean water during the Phanerozoic, but co-variant ${ }^{13} \mathrm{C}$ values for the oxygen isotope measurements have not been included in their published data set. Both ${ }^{13} \mathrm{C}$ and ${ }^{18} \mathrm{O}$ co-variant values are needed to determine if the platform carbonates are original precipitates, have been diagenetically altered at the molecular level, or have been partially altered by meteoric waters during the transformation of the host sediment into limestone [e.g., 77]. Zempolich et al. [78] and Kenny and Knauth [79] analyzed co-variant carbon and oxygen isotope ratios of Proterozoic Beck Spring carbonates to argue that the Late Proterozoic (Beck Spring) ocean was not significantly different from modern sea water. Clumped isotope thermometery is a new approach that uses isotopologues (which are independent of the bulk isotopic composition) to examine the temperature dependence of bond formation between two rare, heavy isotopes within a single molecule to independently determine the $\delta^{18} \mathrm{O}$ value of the fluid in a carbonate sample [80-83]. Cummins et al. [84] used clumped isotope analysis to address the complicated uncertainties related to diagenetic alteration of $\delta^{18} \mathrm{O}$ in carbonates used to estimate the oxygen isotopic composition of past seawater. Cummins et al. [84] measured a large suite of well-preserved Silurian (ca. $433 \mathrm{Ma}$ ) carbonate fossils and determined that Silurian oceans had oxygen isotopic composition similar to the modern ocean. Clumped isotope research of non-icehouse carbonates from other geologic time periods has also been reported yielding similar results [85]. Collectively, the clumped isotope research largely supports previous studies by Knauth and Epstein [45] and Knauth and Roberts [76] which suggest that the $\delta^{18} \mathrm{O}$ of Earth's ocean waters, during non-icehouse conditions, have remained broadly consistent through the Late Proterozoic. As such, palaeotemperature estimates based on oxygen and hydrogen isotope ratios of chert and silica remain valid until a compelling argument can be presented to the contrary.

Other environmental conditions can also impact the oxygen isotope values of chert and silica. (1) Enrichment of ${ }^{18} \mathrm{O}$ in chert may result if silica precipitation occurred under evaporative conditions. Abruzzese et al. [63] documented a large range of oxygen isotope values $(\sim 20 \%)$ from Eocene and Miocene Epoch lacustrine and fresh water chert which they attributed to large-scale changes in the isotopic composition of lake water due to evaporation. The relatively narrow range of oxygen values of secondary silica from the KF $(<5 \%)$ suggest that evaporative processes were likely insignificant and evaporative enrichment was likely minimal during the crystallization history of the chert. (2) Elevated temperatures from postprecipitation metamorphic processes could produce low oxygen and hydrogen isotope ratios of chert and silica. Metamorphic processes capable of altering oxygen and hydrogen values result in notable and visible changes to silica, including: (a) recrystallization of silica and the formation of mega quartz (>35 $\mu \mathrm{m}$ ); and, (b) thermal annealing of macro- and micro-morphological silica fabrics. Field samples of silica from the KF chert rubble horizons retained drusy, botryoidal and vug-fill silica phases; no pervasive silica-filled veins or post-precipitation alteration was observed. Horizontally stratified sedimentary layers of the KF not influenced by karst processes show no signs of metamorphism and no major faults transect the sample locations. Moreover, the observed isotope values are significantly cooler than if chert had been pervasively altered by hydrothermal fluids which have been measured as low as $\left(\sim 100{ }^{\circ} \mathrm{C}\right)$ but which are often substantially hotter [86]. The location and geology of the study area, coupled with the well-preserved silica forms, indicate that the area has not been altered by hydrothermal activity or post-precipitation metamorphic 
processes, and alteration of original stable isotope values is unlikely.

The KF of northern Arizona was located several degrees north of the palaeoequator along the western shoreline of Pangaea (Fig. 1) during PTB [87-89] which placed the KF in a seasonal, tropical ocean setting [30]. Equatorial winds impacted the western shores of Pangaea across the Panthalassic Ocean and likely would have produced elevated annual precipitation amounts in excess of $2000 \mathrm{~mm}$ per year during the latest Permian [30]. Elevated precipitation in a seasonal tropical ocean setting would have enhanced terrestrial weathering, released a substantial volume of silica, and accelerated karst processes producing the aerially extensive chert rubble breccia of the KF. Roscher et al. [30] ran climate models on the latest Permian and determined that the minimum global annual mean temperature for the pre-mass extinction event was $\sim 18.2{ }^{\circ} \mathrm{C}\left(\sim 3{ }^{\circ} \mathrm{C}\right.$ above the current average $)$. Kiehl and Shields [26] modeled terrestrial seasonal mean surface air temperatures for the late Permian during the climate perturbation (mass extinction) event, and estimated a global seasonal mean average temperature $\sim 7.98{ }^{\circ} \mathrm{C}$ above the current average $\left(\sim 23.2^{\circ} \mathrm{C}\right)$. Coastal regions of western Pangaea were influenced by maritime climate conditions that likely buffered temperature extremes during the end Permian. Results from this study indicate that secondary silica along the western shoreline of Pangaea, at the palaeolatitude of the KF, crystallized at temperatures between $\sim 17$ and $22{ }^{\circ} \mathrm{C}$. The palaeotemperature estimates from this study broadly agree with the global mean temperature estimates modeled by Roscher et al. [30], as well as the seasonal mean surface air temperatures during the climate perturbation (mass extinction) event modeled by Kiehl and Shields [26].

\section{Summary and conclusions}

Drusy, botryoidal and vug-fill silica from the uppermost members of the Kaibab Formation chert rubble in the Marble Canyon (AZ) area contain silica suitable for palaeoclimate analysis inferred from oxygen and hydrogen isotope measurements. Application of the Knauth and Epstein [45] method for assigning palaeotemperatures to isotopic values of chert and silica yield a long-term palaeotemperature range of $\sim 17-22{ }^{\circ} \mathrm{C}$ during the end Permian a few degrees north of the palaeoequator along the western shoreline of Pangaea. Accuracy of these palaeotemperature estimates is subject to certain assumptions inherent in the interpretation of isotopic data. The oxygen and hydrogen isotope values clearly indicate that meteoric (non-marine) waters were present during secondary silica crystallization. Oxygen and hydrogen isotope values of secondary silica from the Kaibab Formation chert rubble breccia are broadly consistent with palaeogeographic climate models that estimate an $\sim 18.2^{\circ} \mathrm{C}$ minimum global annual mean temperature for the latest Permian.

Abbreviations

KF: Kaibab Formation; PTB: Permian-Triassic Boundary; AZ: Arizona.

\section{Acknowledgements}

This research was supported in part by an internal Fort Lewis College Traditional Scholarship and Research grant; the author also contributed personal funds to the research endeavor. Assistance from Dr. Toti Larson is greatly appreciated. Two anonymous reviewers provided helpful comments.

\section{Competing interests}

The author declares that there is no competing interests associated with this research. Partial support from the college had no bearing on the design or execution of this research.

\section{Publisher's Note}

Springer Nature remains neutral with regard to jurisdictional claims in published maps and institutional affiliations.

Received: 13 January 2017 Accepted: 28 December 2017

Published online: 16 January 2018

References

1. Twitchett R (1998) Palaeoenvironments and faunal recovery after the end-Permian mass extinction. Palaeogeo Palaeoclim Palaeoecol 154:27-37

2. Twitchett R, Looy CV, Morante R, Visscher H (2001) Rapid and synchronous collapse of marine and terrestrial ecosystems during the endPermian biotic crisis. Geology 29:351-354

3. Ward PD, Botha J, Buick R, De Kock MO, Erwin DH, Garrison G, Kirschvink $J \mathrm{~L}$, Smith R (2005) Abrupt and gradual extinction among Late Permian land vertebrates in the Karoo Basin, South Africa. Science 307:709-714

4. Raup DM (1979) Size of the Permo-Triassic Bottleneck and its evolutionary implications. Science 206:217-218

5. Erwin DH (1993) The great Paleozoic crisis, life and death in the Permian. Columbia University Press, New York, p 327

6. Erwin DH, Bowring SA, Yugan J (2002) End-Permian mass extinctions: a review. In: Koeberl C, MacLeod KG, eds., Catastrophic events and mass extinctions: impacts and beyond. GSA Spl Paper, vol 356. pp 363-383

7. Benton MJ, Twitchett RJ (2003) How to kill (almost) all life: the end-Permian extinction event. Trends Ecol Evolution 18:358-365

8. Becker L, Poreda RJ, Hunt AG, Bunch TE, Rampino M (2001) Impact Event at the Permian-Triassic Boundary: evidence from Extraterrestrial Noble Gases in Fullerenes. Science 291:1530-1533

9. Krull ES, Retallack GJ (2000) $\delta 13 C$ depth profiles from paleosols across the Permian-Triassic boundary: evidence for methane release. GSA Bull 112:1459-1472

10. Berner RA (2002) Examination of hypotheses for the Permo-Triassic boundary extinction by carbon cycle modeling. Nat Acad Sci Proc 99:4172-4177

11. Retallack GJ, Jahren AH (2008) Methane release from igneous intrusion of coal during late Permian extinction events. J Geol 116:1-20

12. Rothman DH, Fournier GP, French KL, Alm EJ, Boyle EA, Cao C, Summons RE (2014) Methanogenic burst in the end-Permian carbon cycle. PNAS 11:5462-5467

13. Kump LR, Pavlov A, Arthur MA (2005) Massive release of hydrogen sulfide to the surface ocean and atmosphere during intervals of oceanic anoxia. Geol 33:397-400

14. Renne PR, Zichao Z, Richards MA, Black MT, Basu AR (1995) Synchrony and causal relations between Permian-Triassic boundary crises and Siberian flood volcanism. Science 269:1413-1416 
15. Kamo SL, Czamanske GK, Amelin Y, Fedorenko VA, Davis DW, Trofimov VR (2003) Rapid eruption of Siberian flood-volcanic rocks and evidence for coincidence with the Permian-Triassic boundary and mass extinction at 251Ma. EPSL 214:75-91

16. Kidder DL, Worsley TR (2004) Causes and consequences of extreme Permo-Triassic warming to globally equable climate and relation to the Permo-Triassic extinction and recovery. Palaeogeogr Palaeoclim Palaeoecol 203:207-237

17. Cuneo NR (1996) Permian phytogeography in Gondwana. Palaeogeogr Palaeoclim Palaeoecol 125:75-104

18. Chumakov NM, Zharkov MA (2003) Climate during the Permian-Triassic biosphere reorganizations. Article 2. Climate of the Late Permian and Early Triassic: general inferences. Strat Geol Correl 11:361-375

19. Wignall PB, Twitchett RJ (1996) Oceanic anoxia and the end Permian mass extinction. Science 272:1155-1158

20. Isozaki Y (1997) Permo-Triassic boundary super-anoxia and stratified superocean: records from lost deep sea. Science 276:235-238

21. Grice K, Cao C, Love GD, Böttcher ME, Twitchett RJ, Grosjean E, Summons RE, Turgeon SC, Dunning W, Jin Y (2005) Photic zone euxinia during the Permian-Triassic superanoxic event. Science 307:706-709

22. Xie S, Pancost RD, Huang J, Wignall PB, Yu J, Tang X, Chen L, Huang X, Lai $X$ (2007) Changes in the global carbon cycle occurred as two episodes during the Permian-Triassic crisis. Geology 25:1083-1086

23. Bowring SA, Erwin DH, Jin YG, Martin MW, Davidek K, Wang W (1998) U/ $\mathrm{Pb}$ zircon geochronology and tempo of the end-Permian mass extinct tion. Science 280:1039-1045

24. Mundil KR, Ludwig I, Metcalfe PR, Renne PR (2004) Age and timing of the Permian mass extinctions: U/Pb dating of closed-system zircons. Science 305:1760-1763

25. Shen S, Crowley JL, Wang Y, Bowring SA, Erwin DH, Sadler PM, Cao C, Rothman DH, Henderson CM, Ramezani J, Zhang H, Shen Y, Wang X, Wang W, Mu L, Li W, Tang Y, Liu X, Liu L, Zeng Y, Jiang Y, Jin Y (2011) Calibrating the end-Permian mass extinction. Science 334:1367-1372

26. Kiehl JT, Shields CA (2005) Climate simulation of the latest Permian: implications for mass extinction. Geology 33:757-760

27. Holser WT, Schönlaub H-P, Attrep M Jr, Boeckelmann K, Klein P, Magaritz M, Orth CJ, Fenninger A, Jenny C, Kralik M, Mauritsch H, Pak E, Schramm JM, Stattegger K, Schmöller R (1989) A unique geochemical record at the Permian/Triassic boundary. Nature 337:39-44

28. Retallack GJ (1995) Permian-Triassic life crisis on land. Science 267:77-80

29. Retallack GJ, Smith RMH, Ward PD (2003) Vertebrate extinction across Permian-Triassic boundary in Karoo Basin, South Africa. GSA Bull 115:1133-1152

30. Roscher M, Stordal F, Svensen H (2011) The effect of global warming and global cooling on the distribution of the latest Permian climate zones. Palaeogeogr Palaeoclim Palaeoecol 309:186-200

31. McKee ED (1938) The environment and history of the Toroweap and Kaibab formations on Northern Arizona and Southern Utah. Carnegie Institute Publication, vol 492. p 268

32. Cheevers CW, Rawson RR (1979) Facies analysis of the Kaibab Formation in Northern Arizona, Southern Utah, and Southern Nevada. In: Baars D (ed) Permianland. Four Corners Geol Soc. pp 105-133

33. Cheevers, CW (1980) Stratigraphic analysis of the Kaibab Formation in Northern Arizona, Southern Utah, and Southern Nevada. Unpublished MS Thesis, Northern Arizona University, Flagstaff, AZ, p 144

34. Hopkins RL (1986) Depositional Environments and Diagenesis of the Fossil Mountain Member of the Kaibab Formation (Permian), Grand Canyon, Arizona. Unpublished MS Thesis, Northern Arizona University, Flagstaff, $A Z, p 244$

35. Hopkins RL (1990) Kaibab Formation. In: Morales M, Beus SS (eds) Grand Canyon Geology. Oxford University Press, Oxford, pp 225-245

36. Stewart JH, Poole FG, Wilson RF (1972) Stratigraphy and origin of the Triassic Moenkopi Formation and related strata in the Colorado Plateau Region. USGS Prof Paper, vol 691. p 195

37. McFadden KA (2004) End-Permian Karst stratigraphy and geochemistry at the Kaibab-Moenkopi contact and its relationship to the Permian-Triassic boundary for northern Arizona. Unpublished MS Thesis, Arizona State University, Tempe, AZ. p 59

38. McFadden KA, Knauth LP (2004) End-Permian Karst Stratigraphy and Geochemistry at the Kaibab-Moenkopi contact and its relationship to the Permian-Triassic boundary for Northern Arizona. GSA Abst 36:252
39. Huntoon JE, Dubiel RF, Stanesco JD (1994) Tectonic influence on development of the Permian-Triassic unconformity and basal Triassic strata, Paradox Basin, southeastern Utah. In: Caputo MV, Peterson JA, Franczyk KA (eds) Mesozoic systems of the rocky mountain Region. Society of Economic Geologists, Littleton, pp 109-131

40. Erwin DH (1994) The Permo-Triassic extinction. Nature 367:231-236

41. Davies C, Allen MB, Buslov MM, Safonova I (2010) Deposition in the Kuznetsk Basin, Siberia: insights into the Permian-Triassic transition and the Mesozoic evolution of central Asia. Palaeogeogr Palaeoclim Palaeoecol 295:307-322

42. Tabor N, Smith RMN, Steyer S, Huffington RM (2011) The Permian Moradi Formation of northern Niger: paleosol morphology, petrography, and mineralogy. Palaeogeogr Palaeoclim Palaeoecol 299:200-213

43. Retallack GJ (2012) Permian and Triassic greenhouse crises. Gondwana Res 24:90-103

44. Peters NA, Huntington KW, Hoke GD (2013) Hot or not? Impact of seasonally variable soil carbonate formation on paleotemperature and O-isotope records from clumped isotope thermometry. EPSL 362:208-218

45. Knauth LP, Epstein S (1976) Hydrogen and oxygen isotope ratios in nodular and bedded cherts. Geochim Cosmochim Acta 40:1095-1108

46. Kenny R, Knauth LP (1992) Continental paleoclimates from $\delta D$ and $\delta 180$ of secondary silica in paleokarst chert lags. Geology 20:219-222

47. Kenny R (2010) Continental paleoclimate estimates from the late Mississippian Redwall karst event: northern and north-central Arizona (USA). Carb Evap 25:297-302

48. Sharp ZD (1990) A laser-based microanalytical method for the in situ determination of oxygen isotope ratios of silicates and oxides. Geochim Cosmochim Acta 54:1353-1357

49. Sharp ZD, Atudorei VN, Durakiewicz T (2001) A rapid method for determination of hydrogen and oxygen isotope ratios from water and solid hydrous substances. Chem Geol 178:197-210

50. Morey GW, Fournier RO, Row JJ (1962) The solubility of quartz in water in the temperature interval from $25^{\circ} \mathrm{C}$ to $300^{\circ} \mathrm{C}$. Geochimica Cosmochimica Acta 26:1029-1043

51. Knauth LP (1997) A model for the origin of chert in limestone. Geology 7:274-277

52. Iler RK (1979) The Chemistry of Silica: solubility, polymerization, colloid and surface properties, and biochemistry. Wiley, Hoboken, p 866

53. Bennett PC (1991) Quartz dissolution in organic-rich aqueous systems. Geochim et Cosmochim Acta 55:1781-1798

54. Livingstone DA (1963) Chemical composition of rivers and lakes. USGS Prof Paper 440-G. p 64

55. White WB, Jefferson GL, Haman JF (1966) Quartzite karst in south-central Venezuela. Int J Speleol 2:309-314

56. Martini JEJ (1979) Karst in black reef quartzite near Kaapsehoop, Eastern Transvaal. Annals Geol Soc So Africa 13:115-128

57. Chalcraft D, Pye K (1984) Humid tropical weathering of quartzite in south eastern Venezuela. Zeit Geomorphol 28:321-332

58. MacKenzie FT, Gees R (1971) Quartz: synthesis at earth-surface conditions. Science 173:533-535

59. Rimstidt JD (1997) Quartz solubility at low temperatures. Geochim Cosmochim Acta 61:2553-2558

60. Knauth LP (1994) Petrogenesis of Chert. In: Heaney P (ed) Silica: physical behavior, geochemistry, and materials applications, reviews in mineralogy, vol 29. Mineralogical Society o America, Chantilly, pp 233-258

61. Skotnicki SJ, Knauth LP (2007) The middle Proterozoic Mescal paleokarst, central Arizona, USA: karst development, silicification, and cave deposits. J Sed Res 77:1046-1062

62. Hill C, Forti P (1997) Cave minerals of the world, 2nd edn. National Speleological Society, Huntsville, p 463

63. Abruzzese MJ, Waldbauer JR, Chamberlain CP (2005) Oxygen and hydrogen isotope ratios in freshwater chert as indicators of ancient climate and hydrologic regime. Geochim Cosmochim Acta 69:1377-1390

64. Knauth LP, Lowe DR (2003) High Archean climatic temperature inferred from oxygen isotope geochemistry of cherts in the $3.5 \mathrm{Ga}$ Swaziland Supergroup, South Africa. GSA Bull 115:566-580

65. Hren MT, Tice MM, Chamberlain CP (2009) Oxygen and hydrogen isotope evidence for a temperate climate 3.42 billion years ago. Nature 462:205-208

66. Sharp ZD, Gibbons JA, Maltsev O, Atudorei V, Pack A, Sengupta S, Shock EL, Knauth LP (2016) A calibration of the triple oxygen isotope 
fractionation in the $\mathrm{SiO}_{2}-\mathrm{H}_{2} \mathrm{O}$ system and applications to natural samples. Geochim Cosmochim Acta 186:105-119

67. Schopf JW, Kudryavtsev AB, Czaja AD, Tripathi AB (2007) Evidence of Archean life: stromatolites and microfossils. Precambrian Res 158:141-155

68. Schopf JW, Kitajima K, Spicuzza MJ, Kudryavtev AB, Valley JW (2017) SIMS analyses of the oldest known assemblage of microfossils document their taxon-correlated carbon isotope compositions. Proc Natl Acad Sci. https://doi.org/10.1073/pnas.1718063115

69. Knoll AH (1992) Vendian microfossils in metasedimentary cherts of the Scotia group, Prins Karls Forland, Svalbard. Palaeontol 35:751-774

70. Schopf JW (1993) Microfossils of the early Archean Apex Chert: new evidence of the antiquity of life. Science 260:640-646

71. Horodyski RJ, Knauth LP (1994) Life on land in the Precambrian. Science 263:494-498

72. Sugitani K, Greyb K, Allwood A, Nagaoka T, Mimura M, Minami M, Marshall CP, Van Kranendonk MJ, Walter MR (2007) Diverse microstructures from Archaean chert from the Mount Goldsworthy-Mount Grant area, Pilbara Craton, Western Australia: microfossils, dubiofossils, or pseudofossils? Precambrian Res 158:228-262

73. Brasier MD, Green OR, Jephcoat AP, Kleppe AK, Van Kranendonk MJ, Lindsay JF, Steele A, Grassineau NV (2002) Questioning the evidence for Earth's oldest fossils. Nature 416:76-81

74. Veizer J, Fritz P, Jones B (1986) Geochemistry of brachiopods: oxygen and carbon isotopic records of Paleozoic oceans. Geochim Cosmochim Acta 50:1679-1696

75. Veizer J, Prokoph A (2015) Temperatures and oxygen isotopic composition of Phanerozoic oceans. Earth Sci Rev 146:92-104

76. Knauth LP, Roberts SK (1991) The hydrogen and oxygen isotopic history of the Silurian-Permian hydrosphere as determined by direct measurement of fossil water. In: Stable isotope geochemistry: a tribute to Samuel Epstein. Geochemical Society, vol 3. pp 91-104

77. Knauth LP, Kennedy MJ (2009) The late Precambrian greening of the Earth. Nature 460:728-732

78. Zempolich WG, Wilkinson BH, Lohmann KC (1988) Diagenesis of late proterozoic carbonates: the Beck Spring Dolomite of Eastern California. J Sed Res 58:656-672
79. Kenny R, Knauth LP (2001) Stable isotope variations in the Neoproterozoic Beck Spring Dolomite and Mesoproterozoic Mescal Limestone paleokarst: implications for life on land in the Precambrian. GSA Bull 113:650-658

80. Eiler JM (2007) "Clumped-isotope" geochemistry-The study of naturallyoccurring, multiply-substituted isotopologues. ESPL 262:309-327

81. Eiler JM (2011) Paleoclimate reconstruction using carbonate clumped isotope thermometry. Quaternary Sci Rev 30:3575-3588

82. Henkes GA, Passey BH, Wanamaker AD Jr, Grossman EL, Ambrose WG Jr, Carroll ML (2013) Carbonate clumped isotope compositions of modern marine mollusk and brachiopod shells. Geochim Cosmochim Acta 106:307-325

83. Eiler JM, Bergquist B, Bourg I, Cartigny P, Farquhar J, Gagnon A, Guo W, Halevy I, Hofmann A, Larson TE, Levin N, Schauble EA, Stolper D (2014) Frontiers of stable isotope geoscience. Chem Geol 372:119-143

84. Cummins RC, Finnegan S, Fike DA, Eiler JM, Fischer WW (2014) Carbonate clumped isotope constraints on Silurian ocean temperature and seawater 8180 . Geochim Cosmochim Acta 140:241-258

85. Henkes GA, Passey BH, Grossman EL, Shenton BJ, Perez-Huerta A, Yancey TE (2014) Temperature limits for preservation of primary calcite clumped isotope paleotemperatures. Geochim Cosmochim Acta 139:362-382

86. Coumou D, Driesner T, Heinrich CA (2008) The structure and dynamics of Mid-Ocean Ridge hydrothermal systems. Science 321:1825-1828

87. Rees PM, Ziegler AM, Gibbs MT, Kutzbach JE, Behling PJ, Rowley DB (2002) Permian phytogeographic patterns and climate data/model comparisons. J Geol 110:1-31

88. Ziegler AM, Hulver ML, Rowley DB (1997) Permian world topography and climate. In: Martini IP (ed) Late glacial and post-glacial environmental changes: Quaternary. Oxford University Press, Carboniferous-Permian and Proterozoic, pp 111-146

89. Scotese CR (2001) Atlas of Earth History, vol 1. Paleogeography, PALEOMAP Project, p 52

\section{Submit your manuscript to a SpringerOpen ${ }^{\odot}$ journal and benefit from:}

- Convenient online submission

- Rigorous peer review

- Open access: articles freely available online

- High visibility within the field

- Retaining the copyright to your article

Submit your next manuscript at $\boldsymbol{\nabla}$ springeropen.com 